\title{
Lactobacillus delbrueckii ssp. bulgaricus OLL1073R-1 feeding enhances humoral immune responses, which are suppressed by the antiviral neuraminidase inhibitor oseltamivir in influenza A virus-infected mice
}

\author{
E. Takahashi, T. Sawabuchi, T. Kimoto, S. Sakai, and H. Kido* \\ Division of Enzyme Chemistry, Institute for Enzyme Research, Tokushima University, 3-15-18, Kuramoto-cho, Tokushima-city, Tokushima, \\ 770-8503, Japan
}

\section{ABSTRACT}

Antiviral neuraminidase inhibitors, such as oseltamivir, zanamivir, and peramivir, are widely used for treatment of influenza virus infection. We reported previously that oseltamivir inhibits the viral growth cycle, ameliorates symptoms, and reduces viral antigen quantities. Suppressed viral antigen production, however, induces a reduction of acquired antiviral humoral immunity, and increases the incidence of re-infection rate in the following year. To achieve effective treatment of influenza virus infection, it is necessary to overcome these adverse effects of antiviral neuraminidase inhibitors. Feeding of yogurt fermented with Lactobacillus delbrueckii ssp. bulgaricus (L. bulgaricus) OLL1073R-1 is reported to have immune-stimulatory effects on influenza virus infection in mice and humans. In the present study, we assessed the effect of feeding $L$. bulgaricus OLL1073R-1 yogurt cultures (YC) on local and systemic humoral immune responses, which were suppressed by oseltamivir treatment, in mice infected with influenza A virus. Yogurt culture $\left(1.14 \times 10^{8} \mathrm{cfu} / 0.4\right.$ $\mathrm{mL}$ per mouse per day) or sterile water (vehicle) was administered by intragastric gavage for $35 \mathrm{~d}$. At d 22, influenza A virus/Puerto Rico/8/34 (H1N1) (PR8; $0.5 \mathrm{pfu} / 15 \mu \mathrm{L}$ per mouse) was instilled intranasally, followed immediately by oral administration of oseltamivir $(50 \mu \mathrm{g} / 100 \mu \mathrm{L}$ per mouse, twice daily) or $5 \%$ methylcellulose $(100 \mu \mathrm{L} /$ mouse $)$ as a vehicle for $13 \mathrm{~d}$. Titers of anti-PR8-specific IgG and IgA in serum and mucosal secretory IgA (S-IgA) and IgG in bronchoalveolar lavage fluid (BALF) were analyzed by ELISA at $14 \mathrm{~d}$ after infection. Oseltamivir significantly suppressed the induction of anti-PR8-specific IgG and $\operatorname{IgA}$ in serum and $\mathrm{S}-\operatorname{IgA}$ and $\operatorname{IgG}$ in BALF after infection. Feeding YC mildly but significantly stimulated produc-

Received January 8, 2019.

Accepted July 17, 2019.

*Corresponding author: kido@tokushima-u.ac.jp tion of PR8-specific IgA in serum, S-IgA in BALF, and IgG in serum without changing the $\operatorname{IgG}_{22}: \mathrm{IgG}_{1}$ ratio. We analyzed the neutralizing activities against PR8 in serum and BALF and found that oseltamivir also reduced protective immunity, and YC feeding abrogated this effect. The immune-stimulatory tendency of YC on anti-PR8-specific IgA and IgG titers in serum and BALF was also detected in mice re-infected with PR8, but the effect was insignificant, unlike the effect of $\mathrm{YC}$ in the initial infection.

Key words: yogurt culture, influenza A virus infection, immunomodulatory effects, oseltamivir

\section{INTRODUCTION}

Influenza is a worldwide public health problem characterized by sudden onset and severe symptoms (Gillim-Ross and Subbarao, 2006). Although influenza vaccination is the best means of prevention, antiviral drugs are effective against influenza infections and are being stockpiled in many countries as part of pandemic response planning. By inhibiting the activity of the influenza virus neuraminidase and blocking the release of virions from the infected cell surface, oseltamivir (OSV), zanamivir, and peramivir have well-established antiviral efficacy based on inhibition of the viral infection cycle, with effective improvement of clinical status and reduction of complications (Hayden et al., 1999; Moscona, 2005).

In the pathogenesis of influenza infection, a coordinated immune response involving both innate and adaptive immunities is important for viral clearance and improvement of clinical outcome (Peiris et al., 2010; Rouse and Sehrawat, 2010). In contrast to the reported beneficial effects of OSV, we demonstrated previously that treatment with this antiviral agent reduces the production of antiviral mucosal secretory $\operatorname{IgA}(\mathbf{S}-\mathbf{I g} \mathbf{A})$ and antiviral $\mathrm{IgG}$ in serum in humans and mice (Sawabuchi et al., 2009; Takahashi et al., 2010). These effects could be detrimental during future re-infection in humans (Shinahara et al., 2013). Furthermore, it has been 
reported that OSV has a negative effect on development of the adaptive immune response by reducing effector and memory $\mathrm{CD} 8^{+} \mathrm{T}$-cell responses to influenza and can thus potentially compromise protective immunity (Marois et al., 2015).

Lactic acid bacteria found in yogurt cultures (YC) and their products are known to enhance the functional activities of immune cells (Meydani and Ha, 2000; Perdigón et al., 2001; de Vos et al., 2017). We used yogurt produced through fermentation of milk by Streptococcus thermophilus and L. bulgaricus OLL1073R-1, an immune-stimulatory exopolysaccharide (EPS)-producing lactic acid bacterial strain. It exhibits marked immunemodulatory effects, such as the activation of biological defense mechanisms and natural killer cell activation, through induction of IFN- $\gamma$ in mice (Makino et al., 2006, 2010, 2016). Furthermore, it was reported recently that L. bulgaricus OLL1073R-1 YC increased IgA secretion in saliva in elderly individuals and protected against invasion by foreign antigens and pathogens through the oral mucosa (Yamamoto et al., 2017).

The aim of the present study was to evaluate the immune-stimulatory effects of L. bulgaricus OLL1073R-1 $\mathrm{YC}$ on the OSV-induced suppression of local and systemic humoral immunity in mice infected with influenza A virus (IAV).

\section{MATERIALS AND METHODS}

\section{Preparation of Yogurt}

Yogurt was fermented with L. bulgaricus OLL1073R-1 and Streptococcus thermophilus OLS3059 as described previously (Makino et al., 2016). The OLL1073R-1 strain was identified as the most robust producer of immune-stimulatory EPS and IFN- $\gamma$ in vitro by screening 139 L. delbrueckii ssp. bulgaricus strains (Makino et al., 2016). Starter culture was fermented by inoculation of pasteurized milk containing $3 \%$ (wt/wt) sucrose with L. bulgaricus OLL1073R-1 $\left(3.5 \times 10^{8} \mathrm{cfu} / \mathrm{g}\right)$ and S. thermophilus OLS3059 $\left(6.8 \times 10^{8} \mathrm{cfu} / \mathrm{g}\right)$, grown at $37^{\circ} \mathrm{C}$ for 18 to $24 \mathrm{~h}$ and then inoculated at $1 \%$ (wt/wt) concentration for a laboratory-scale manufacturing fermentation, which was performed at $43^{\circ} \mathrm{C}$ until culture acidity reached $0.70 \%$.

\section{Animals and Virus Infection}

Six-week-old female BALB/c mice purchased from Japan SLC (Shizuoka, Japan) were used. All mice used in this study were treated according to the Guide for the Care and Use of Laboratory Animals (NRC, 1996). This study was approved by the Animal Care Committee of
Tokushima University (\#T30-38; Tokushima, Japan). The mice ( $\mathrm{n}=20$ per group) received orally $400 \mu \mathrm{L}$ of L. bulgaricus OLL1073R-1 YC $\left(1.14 \times 10^{8} \mathrm{cfu}\right.$; Nagai et al., 2011) or distilled water (DW), as a control, once daily for $35 \mathrm{~d}$. On d 22, the mice were infected intranasally with IAV/Puerto Rico/8/34 (H1N1) (PR8) at a dose of $0.5 \mathrm{pfu}$ (representing $20 \%$ of the median lethal dose, $\mathbf{L D}_{50}$ ), in $15 \mu \mathrm{L}$ of saline under anesthesia by intraperitoneal injection of $62.6 \mathrm{mg}$ of ketamine and $12.4 \mathrm{mg}$ of xylazine per $\mathrm{kg}$ of BW. Immediately after infection, the mice also received orally $50 \mu \mathrm{g}$ of OSV in $100 \mu \mathrm{L}$ of $5 \%$ methylcellulose (MC) as a vehicle or MC alone twice daily $(\mathrm{n}=10$, per group) at a 12 -h interval for $13 \mathrm{~d}$ (Figure 1A).

\section{Quantitative Reverse-Transcription PCR Assays}

Total RNA was extracted from mice lungs with TRIzol Reagent (Ambion, Carlsbad, CA) and reverse transcribed to cDNA using M-MLV reverse transcriptase (Promega Corp., Madison, WI). Relative mRNA levels of viral RNA polymerase $\alpha(\mathbf{P A})$ and $18 \mathrm{~S}$ rRNA were determined by quantitative reverse-transcription PCR (qRT-PCR) with SYBR green mix (Roche Diagnostics, Mannheim, Germany). The following primers were used $\left(5^{\prime}-3^{\prime}\right)$ : PA forward: cggtccaaattcctgctga; PA reverse: cattgggttccttccatcca; $18 \mathrm{~S}$ rRNA forward: aggaattgacggaagggcac; $18 \mathrm{~S}$ rRNA reverse: ggacatctaagggcatcaca. The PCR was initiated at $95^{\circ} \mathrm{C}$ for $10 \mathrm{~min}$ to activate HotStartTaq DNA polymerase (Roche Diagnostics, Mannheim, Germany), followed by 40 cycles of $30 \mathrm{~s}$ of denaturation at $95^{\circ} \mathrm{C}, 30 \mathrm{~s}$ of annealing at $60^{\circ} \mathrm{C}$, and $50 \mathrm{~s}$ of extension at $72^{\circ} \mathrm{C}$.

\section{Measurement of Anti-IAV Antibodies}

After infection of mice with PR8, sera and bronchoalveolar lavage fluid (BALF) samples were collected at $14 \mathrm{~d}$ post-infection and subjected to ELISA for measurement of PR8-specific-IgG, $\operatorname{IgA}$, S-IgA, $\operatorname{IgG}_{1}$, and $\operatorname{IgG}_{2 \mathrm{a}}$ titers. Serum was prepared from blood samples collected from the heart, centrifuged at $2,000 \times g$ for $5 \mathrm{~min}$, and then stored at $-80^{\circ} \mathrm{C}$ until analysis. The BALF samples were obtained by 3 consecutive tracheal and lung infusions and aspirations of $1 \mathrm{~mL}$ of saline, centrifuged at 2,000 $\times g$ for 5 min to remove cellular debris, and stored at $-80^{\circ} \mathrm{C}$ until use. For measurement of anti-IAV antibodies, a 96-well plate (Nunc-Immuno Plate; Thermo Fisher Scientific, Roskilde, Denmark) was coated with $100 \mu \mathrm{L}$ of the split product of PR8 virus $(0.05 \mu \mathrm{g} /$ well $)$ dissolved in PBS, and then blocked with $50 \mathrm{n} M$ Tris-HCl buffer, $\mathrm{pH}$ 8.0, containing 0.14 $M \mathrm{NaCl}$ and $1 \% \mathrm{BSA}$ at $37^{\circ} \mathrm{C}$ for $2 \mathrm{~h}$. Serum samples 
A

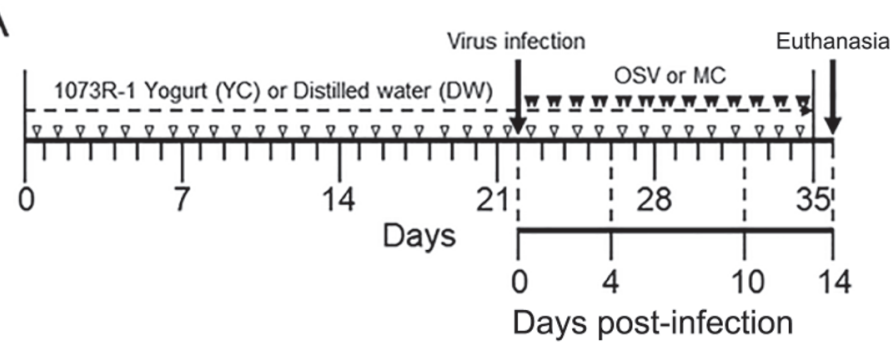

B
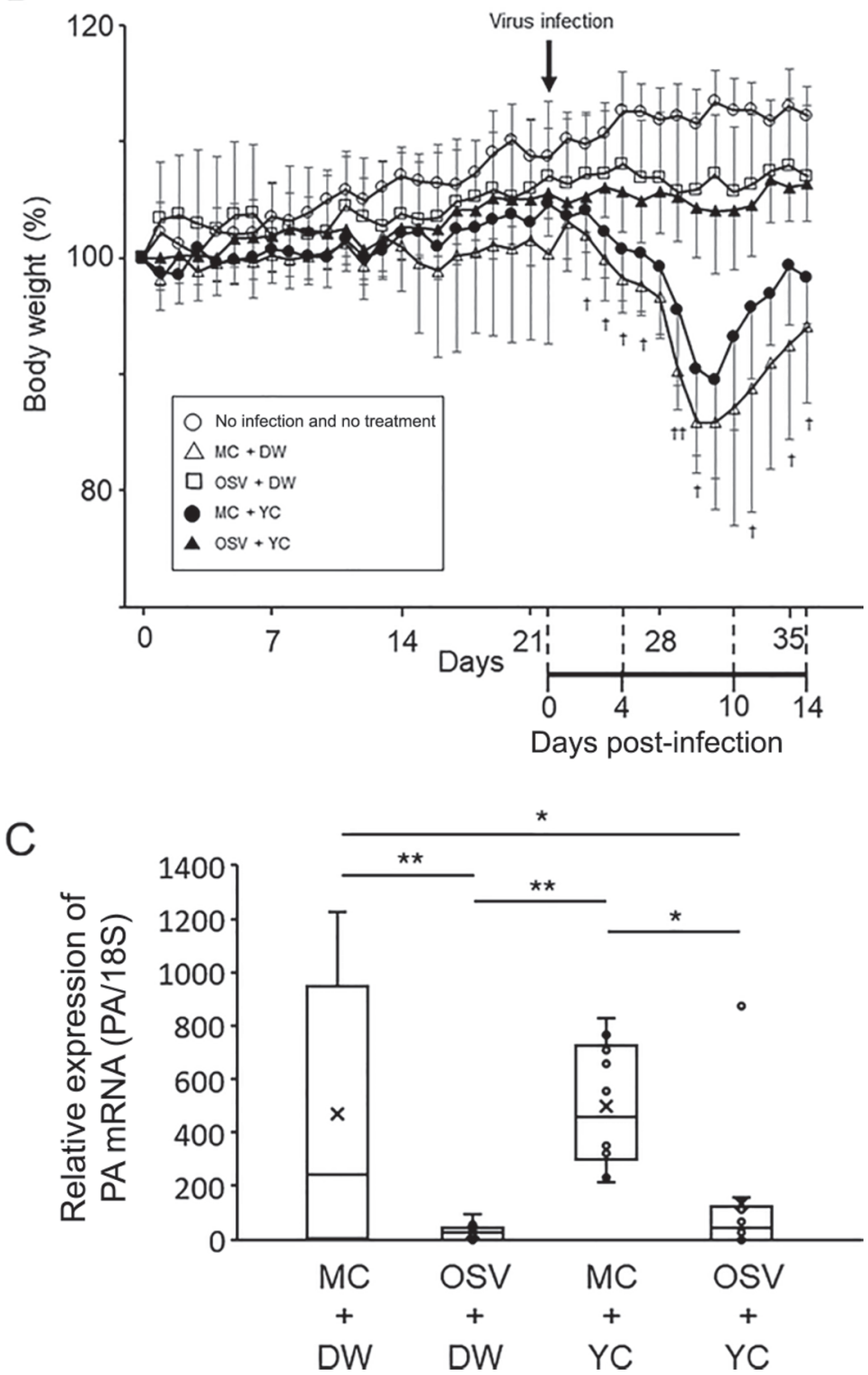

Figure 1. Effects of yogurt culture (YC) feeding on BW loss and influenza A virus (IAV) replication in the lungs of mice infected with IAV followed by treatment with oseltamivir (OSV) or methylcellulose (MC). (A) Time schedule of treatment with Lactobacillus bulgaricus OLL1073R-1 YC or distilled water (DW) in mice once daily for 35 d. Mice were infected with influenza A virus/Puerto Rico/8/34 (H1N1) (PR8) at d 22 followed by treatment with OSV (50 $\mathrm{g} / \mathrm{head}$ ) or MC twice daily for $13 \mathrm{~d}$. (B) Change in initial BW (\%) of each group of mice. Data are mean $\pm \mathrm{SD}(\mathrm{n}=10$ per group). Body weight loss of $(\mathrm{MC}+\mathrm{DW})$-treated infection mice was compared with that of $(\mathrm{MC}+\mathrm{YC})$-treated infection mice. Significant differences $(\dagger P<0.05, \dagger \dagger P<0.01)$ by ANOVA and Bonferroni post-test. (C) Relative viral RNA polymerase $\alpha$ (PA) replication levels in the lungs were analyzed quantitatively by real-time PCR at $4 \mathrm{~d}$ post-infection and data were normalized to expression of $18 \mathrm{~S}$. Data are expressed as median values of 10 mice per group. ${ }^{*} P<0.05,{ }^{* *} P<0.01$; significant differences by ANOVA and Bonferroni post-test. 
diluted with $50 \mathrm{n} M$ Tris-HCl buffer, $\mathrm{pH}$ 8.0, containing $0.14 M \mathrm{NaCl}, 0.05 \%$ Tween-20, and 1\% BSA (TTS), and the BALF samples were allowed to react at $37^{\circ} \mathrm{C}$ for $2 \mathrm{~h}$. After reaction and washing with TTS, the plate was incubated with horseradish peroxidase-conjugated, affinity-purified goat anti-mouse $\operatorname{Ig} \mathrm{A}$, anti-mouse $\mathrm{Ig} \mathrm{G}$, anti-mouse $\mathrm{IgG}_{1}$, and anti-mouse $\operatorname{IgG}_{2 \mathrm{a}}$ antibodies (Bethyl Laboratories Inc., Montgomery, TX) at $37^{\circ} \mathrm{C}$ for $1 \mathrm{~h}$. After washing with TTS, 3,3',5,5'-tetramethylbenzidine (TMB) peroxidase substrate (KPL Inc., Gaithersburg, MD) was added and allowed to develop color at room temperature for $15 \mathrm{~min}$. After adding Stop solution (KPL Inc., Gaithersburg, MD) to the plate, the produced chromogen was measured at $450 \mathrm{~nm}$ using a plate reader (SpectraMax Plus 384 Microplate Reader, Molecular Devices, San Jose, CA). Antibody titers were defined as the reciprocal of the highest dilution of sample for which the optical density (OD) was at least twice the OD of the negative control samples without treatment.

\section{Neutralizing Activity Assay}

Influenza A virus neutralization activity was evaluated using a method described in detail previously (Takahashi et al., 2012). Serum IgG was purified with the IgG purification Kit-G according to the protocol provided by the manufacturer (Dojindo Molecular Technologies Inc., Rockville, MD). The BALF samples were centrifuged at $2,000 \times g$ and supernatants were recovered. To measure the neutralizing activities of BALF and IgG in serum, optimal doses of IAV PR8 (3,000 pfu for BALF and 1,450 pfu for serum) were mixed with BALF and purified serum IgG, respectively, on ice for $2 \mathrm{~h}$ as a pretreatment. Because the neutralizing activity of BALF was relatively higher than that of serum, we inoculated a higher dose of IAV PR8 to determine the difference in neutralizing activity of BALF in each group. Confluent monolayers of Madin-Darby canine kidney (MDCK) cells in 96-well plates were washed twice with PBS and then treated for $1 \mathrm{~h}$ with the reaction mixtures for infection. Then, the cells were washed with PBS and cultured for $16 \mathrm{~h}$ in Minimum Essential Medium supplemented with $0.1 \%$ BSA and $50 \mu \mathrm{g} /$ $\mathrm{mL}$ gentamicin. In the next step, cells were fixed with $4 \%$ paraformaldehyde in PBS, and permeabilized with $0.3 \%$ Triton-X-100 in PBS. To detect infected cells, anti-influenza virus nucleoprotein monoclonal antibody (QED Bioscience, San Diego, CA) and horseradish peroxidase-labeled anti-mouse IgG were used. The viral protein was visualized using the TrueBlue peroxidase substrate (KPL Inc.), and the number of cell foci/well was counted under a stereomicroscope.

\section{Statistical Analysis}

The PR8-specific immunoglobulin titers are expressed as mean \pm standard deviation, and PR8 replication rates are given as median (interquartile range) values $(\mathrm{n}=10)$. Differences between experimental groups were analyzed for statistical significance by ANOVA with Bonferroni post-test and an unpaired Student's $t$-test, using KaleidaGraph 4.5 software (Synergy Software, Reading, PA). A $P$-value $<0.05$ was considered to denote the presence of statistical significance.

\section{RESULTS}

\section{Effects of YC Feeding on BW Loss and IAV Replication in the Lungs of Infected Mice}

First, we analyzed the effects of orally administered L. bulgaricus OLL1073R-1 (400 $\left.\mu \mathrm{L} ; 1.14 \times 10^{8} \mathrm{cfu}\right) \mathrm{YC}$ or DW once daily for $35 \mathrm{~d}$ on BW (Figure 1). At d 22, the mice were infected intranasally with PR8. We used another group of mice to monitor the natural change in BW. Mice of the latter group did not receive either YC or DW and were not inoculated with PR8. No significant differences in changes in BW were detected among the 3 groups before PR8 infection.

We reported previously that IAV infection induced persistent BW loss in mice, whereas treatment with OSV inhibited viral replication and protected against BW loss (Takahashi et al., 2010, 2012). Each group of mice treated with $\mathrm{YC}$ or DW was infected with PR8 and then divided into 2 groups treated orally with OSV or MC as the vehicle. Changes in percent of initial BW of these 4 groups of mice $(n=10)$ and the single group without pretreatment or infection were analyzed until d 36 (Figure 1B). Continuous BW loss associated with PR8 infection was noted after infection in both the $(\mathrm{MC}+\mathrm{DW})$ and $(\mathrm{MC}+\mathrm{YC})$ infection groups. Recovery of BW loss was observed after $10 \mathrm{~d}$ post-infection in both groups. The maximal BW loss was 14.1 and $10.5 \%$ in the $(\mathrm{MC}+\mathrm{DW})$ and $(\mathrm{MC}+\mathrm{YC})$ infected mice, respectively. Feeding L. bulgaricus OLL1073R-1 YC significantly protected against $\mathrm{BW}$ loss in $(\mathrm{MC}+\mathrm{YC})$ infected mice compared with the control $(\mathrm{MC}+\mathrm{DW})$. In contrast, no persistent BW loss was detected in $(\mathrm{OSV}+\mathrm{YC})$ or $(\mathrm{OSV}+\mathrm{DW})$ groups and no significant difference in BW loss was detected between the 2 groups. In mice that showed BW loss, amounts of water and food consumption also decreased after PR8 infection (data not shown). None of the animals in any of the groups died during the experimental period.

Relative viral PA replication rates in the lungs of each group of mice at $4 \mathrm{~d}$ post-infection, a maximal 
PR8 replication day (Yamane et al., 2014), are shown in Figure 1C. Treatment with OSV significantly $(P$ $<0.05)$ suppressed PA replication in $(\mathrm{OSV}+\mathrm{DW})$ and $(\mathrm{OSV}+\mathrm{YC})$ groups compared with $(\mathrm{MC}+\mathrm{DW})$ and $(\mathrm{MC}+\mathrm{YC})$, respectively. Feeding L. bulgaricus OLL1073R-1 YC did not change the PA replication rates in $(\mathrm{MC}+\mathrm{YC})$ and $(\mathrm{OSV}+\mathrm{YC})$ groups compared with $(\mathrm{MC}+\mathrm{DW})$ and $(\mathrm{OSV}+\mathrm{DW})$ groups, respectively, under the assay conditions used.

\section{Feeding YC Increased PR8-Specific IgG and IgA in Serum and S-IgA in BALF}

Next, we analyzed the effects of $L$. bulgaricus OLL1073R-1 YC feeding on the levels of PR8-specific $\operatorname{IgG}$ and $\operatorname{IgA}$ in serum and S-IgA in BALF at $14 \mathrm{~d}$ postinfection in each group. The antibody titers of PR8specific IgA in serum and S-IgA in BALF and those of PR8-specific IgG in serum and BALF of infected mice were measured by ELISA. The $(\mathrm{OSV}+\mathrm{DW})$-treated infection group had significantly reduced $(P<0.01)$ PR8-specific titers of IgA in serum and S-IgA in BALF compared with the $(\mathrm{MC}+\mathrm{DW})$ infection group (Figure 2). These immune-suppressive effects of OSV were consistent with those reported previously by our group (Takahashi et al., 2010, 2012). Feeding L. bulgaricus OLL1073R-1 YC once daily in (OSV+YC)-treated infection mice resulted in a mild but significant increase $(P<0.05)$ in the levels of anti-PR8-specific IgA titers in serum and S-IgA in BALF compared with $(\mathrm{OSV}+\mathrm{DW})$ infection mice (Figure 2). However, without OSV treatment, we detected no significant differences in titers between $(\mathrm{MC}+\mathrm{DW})$ and $(\mathrm{MC}+\mathrm{YC})$ infection groups. These results suggest that the immune-stimulating effects of YC were significant under suppressed immunity conditions in OSV-treated infected mice but not in mice without OSV treatment.

In addition, treatment with OSV significantly suppressed $(P<0.05)$ the levels of PR8-specific IgG titers in both serum and BALF (Figure 3). Feeding of $L$. bulgaricus OLL1073R-1 YC once daily significantly prevented $(P<0.05)$ the decrease in production of $\mathrm{IgG}$ in serum of (OSV+YC)-treated infection mice. However, the above treatments had no significant effect on IgG titers in BALF of (OSV+YC) infection mice compared with $(\mathrm{OSV}+\mathrm{DW})$ infection mice, although a weak tendency for immune stimulation by YC feeding was detected.

We also analyzed the levels of PR8-specific IgG subtypes, including $\operatorname{IgG}_{1}$ and $\operatorname{IgG}_{2 \mathrm{a}}$ levels and $\operatorname{IgG}_{2 \mathrm{a}}: \mathrm{IgG}_{1}$ ratio in serum and BALF (Table 1). The OSV treatment significantly reduced $(P<0.05)$ PR8-specific IgG1 and $\mathrm{IgG}_{2 \mathrm{a}}$ levels in serum and BALF in the $(\mathrm{OSV}+\mathrm{DW})$ in- fection group compared with the $(\mathrm{MC}+\mathrm{DW})$ infection group. Feeding $\mathrm{YC}$ in the (OSV+YC) group resulted in significant increases $(P<0.05)$ in $\mathrm{PR} 8$-specific $\operatorname{IgG}_{2 \mathrm{a}}$ levels in serum and $\operatorname{IgG}_{1}$ levels in BALF compared with the $(\mathrm{OSV}+\mathrm{DW})$ group. In contrast, the combination of $\mathrm{OSV}+\mathrm{YC}$ tended to increase $\mathrm{Ig}_{1}$ levels in serum and $\mathrm{IgG}_{2 \mathrm{a}}$ levels in BALF compared with $\mathrm{OSV}+\mathrm{DW}$, albeit insignificantly. These results indicate that YC predominantly stimulates an increase in the levels of PR8-specific T helper (Th)1-type immunity of $\operatorname{IgG}_{2 \mathrm{a}}$ in serum and Th2-type immunity of $\operatorname{IgG}_{1}$ in BALF of infected mice, without significantly changing $\operatorname{IgG}_{2 \mathrm{a}}: \operatorname{IgG}_{1}$ in serum and BALF.
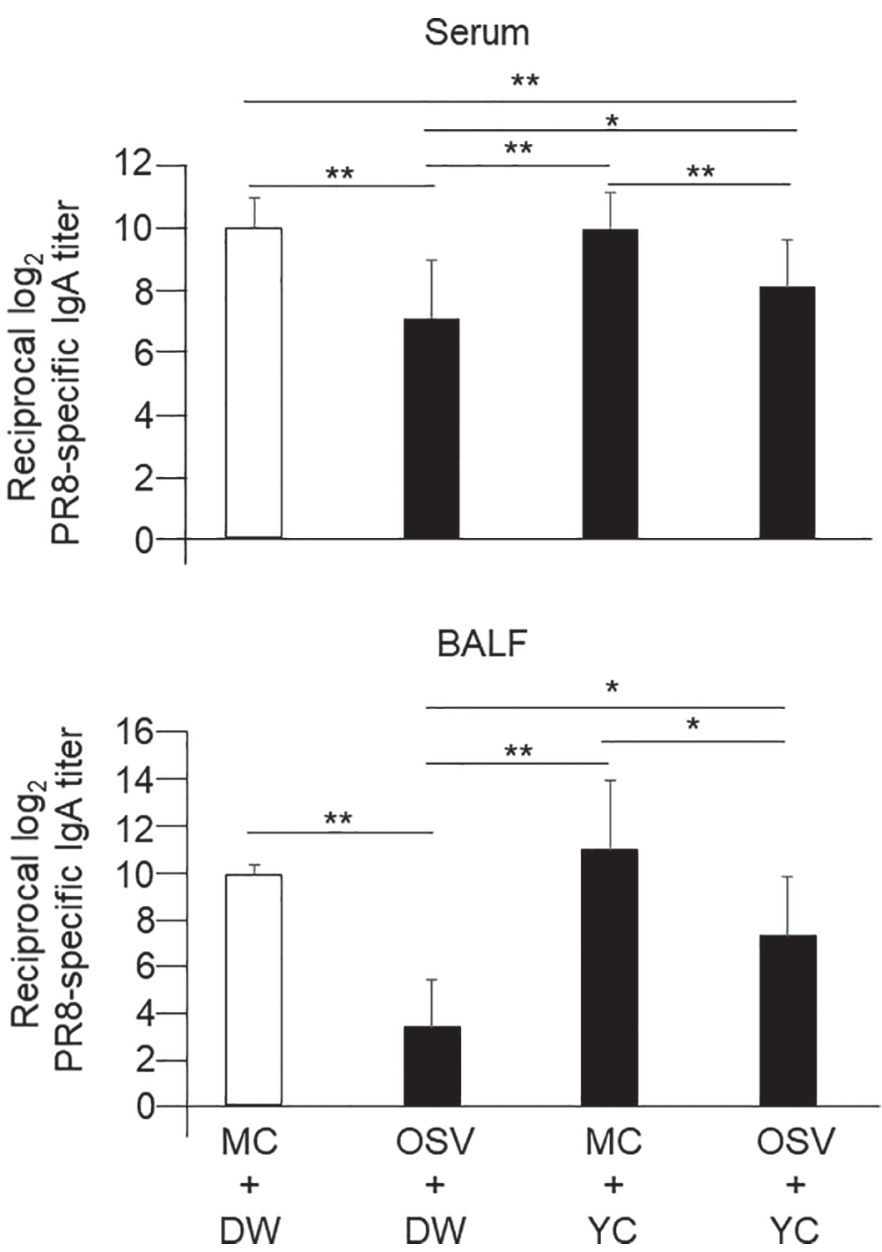

Figure 2. Oseltamivir (OSV) suppressed and yogurt culture (YC) stimulated antiviral IgA production in serum and secretory (S)-IgA in bronchoalveolar lavage fluid (BALF) of mice infected with influenza A virus/Puerto Rico/8/34 (H1N1) (PR8). Mice ingested YC or distilled water (DW) for $35 \mathrm{~d}$ as shown in Figure 1A. During treatment, mice were infected with PR 8 at d 22 followed by treatment with OSV or methylcellulose (MC) twice daily for $13 \mathrm{~d}$. The PR8-specific IgA titers in serum and S-IgA titers in BALF were measured at $14 \mathrm{~d}$ postinfection by ELISA. Data are mean $\pm \mathrm{SD}\left(\mathrm{n}=10\right.$ per group); ${ }^{*} P<$ $0.05,{ }^{* *} P<0.01$, by ANOVA and Bonferroni post-test. 

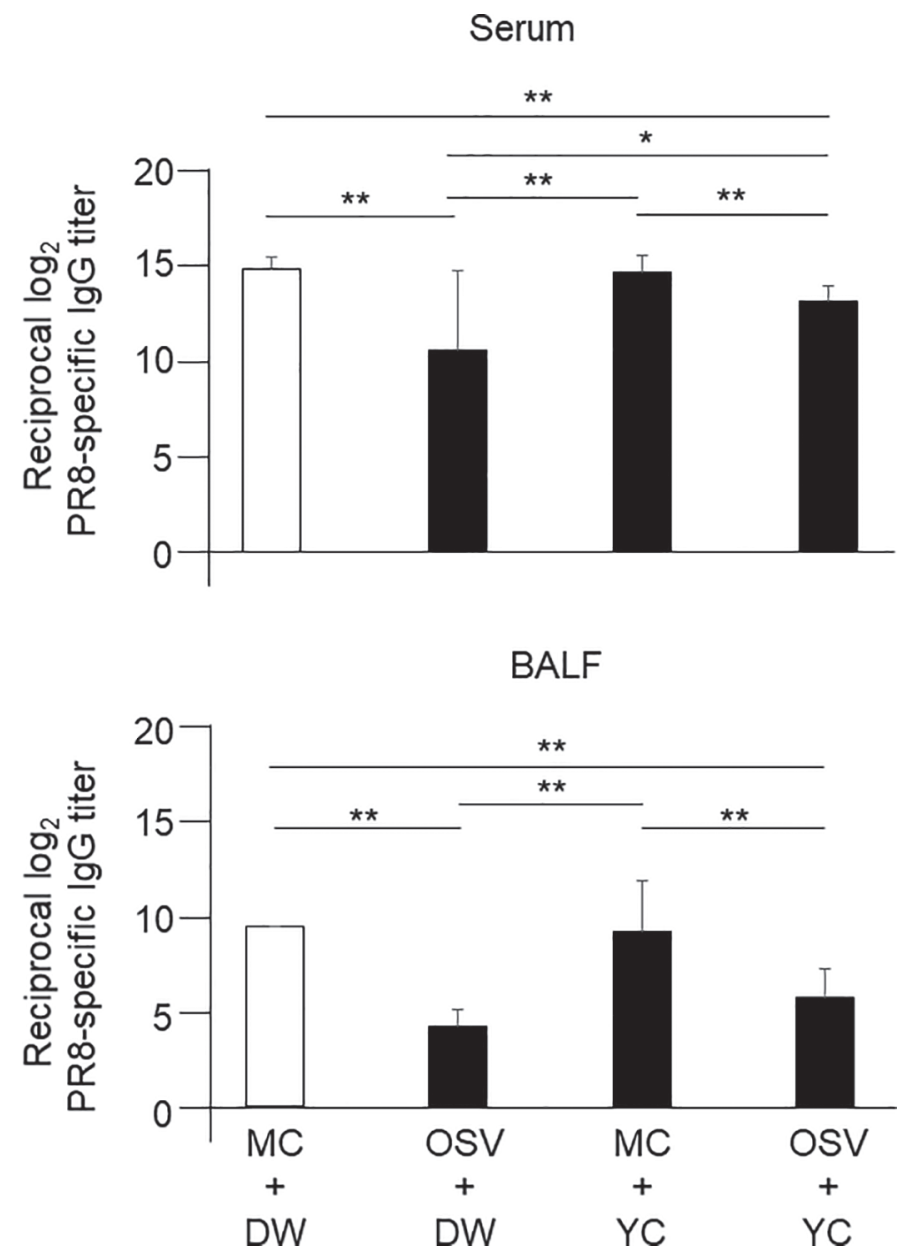

Figure 3. Oseltamivir (OSV) suppressed and yogurt culture (YC) stimulated antiviral IgG production in serum and bronchoalveolar lavage fluid (BALF) of mice infected with influenza $A$ virus/Puerto Rico/8/34 (H1N1) (PR8). Mice ingested YC or distilled water (DW) for $35 \mathrm{~d}$. During treatment, mice were infected with PR8 at d 22 followed by treatment with OSV or methylcellulose (MC) twice daily for $13 \mathrm{~d}$. The PR8-specific IgA titers in serum and secretory (S)-IgA titers in BALF were measured at $14 \mathrm{~d}$ post-infection by ELISA. Data are mean $\pm \mathrm{SD}\left(\mathrm{n}=10\right.$ per group); ${ }^{*} P<0.05,{ }^{* *} P<0.01$, by ANOVA and Bonferroni post-test.

\section{Effects of YC Feeding on Neutralizing Activities of BALF and Serum}

We also investigated the effects of $L$. bulgaricus OLL1073R-1 YC feeding on protective immunity by analyzing the neutralizing activities of PR8-specific antibodies (Figure 4). In these experiments, the PR8 virus was incubated with BALF or purified IgG from serum prepared at $14 \mathrm{~d}$ post-infection as a pretreatment for neutralization, and then the infectivity of the neutralized virus in solution was analyzed by adding the samples to MDCK cells. In this study, neutralization activity was represented by the mean number of foci of infected cells/well. The BALF and serum IgG from the $(\mathrm{MC}+\mathrm{DW})$ infection group showed marked neutralization activities and few foci of infection compared with uninfected mice. In contrast, significantly higher numbers of foci $(P<0.05)$ were detected in BALF and serum IgG from the (OSV+DW) infection group compared with the $(\mathrm{MC}+\mathrm{DW})$ group, indicating that OSV suppressed the induction of protective immunity of BALF and serum. The mean numbers of foci found in serum and BALF from the $(\mathrm{OSV}+\mathrm{YC})$ infection group were significantly lower $(P<0.05)$ than those from the (OSV+DW) infection group, indicating that YC feeding increased not only PR8-specific IgA and $\operatorname{IgG}$ titers but also their neutralization activities in serum and BALF. These results suggest that $L$. bulgaricus OLL1073R-1 YC feeding significantly stimulates induction of acquired humoral immunity with an increase in antiviral neutralizing activities in serum and BALF in infected mice treated with OSV.

\section{Effects of YC Feeding on Protective Immunity in Re-Infected Mice}

We analyzed effects of $L$. bulgaricus OLL1073R-1 YC feeding on re-infected mice. Mice were treated with YC or DW for $35 \mathrm{~d}$ and infected with PR8 at a dose of 0.5 pfu on d 22 followed by treatment with OSV or MC for $13 \mathrm{~d}$ as described in Figure 1A. Then, 4 groups of mice $(\mathrm{MC}+\mathrm{DW}, \mathrm{OSV}+\mathrm{DW}, \mathrm{MC}+\mathrm{YC}$, and $\mathrm{OSV}+\mathrm{YC}$ infection groups) were kept without any treatment for another $11 \mathrm{~d}$ and re-infected with an extremely high dose $(10,000 \mathrm{pfu})$ of PR8 $\left(4,000 \times \mathrm{LD}_{50}\right)$. None of the animals died following re-infection. Viral replication in the lungs and anti-PR8-specific IgG and IgA levels in serum and BALF were analyzed at $4 \mathrm{~d}$ after reinfection (Figure 5). Relative PA expression levels in all groups in Figure 5A were less than 1/100 of those of the initial infection. The results indicated that protective immunity induced by initial infection works well. Under the experimental conditions used here, we found that relative PA expression levels of $(\mathrm{OSV}+\mathrm{DW})$ infected mice were significantly higher $(P<0.05)$ than those of $(\mathrm{MC}+\mathrm{DW})$ and $(\mathrm{MC}+\mathrm{YC})$ infected mice. In addition, relative PA expression levels of $(\mathrm{OSV}+\mathrm{YC})$ mice tended to be lower than (OSV+DW) mice. Anti-PR8specific IgA and IgG titers in serum and BALF in all 4 treatment groups at $4 \mathrm{~d}$ after re-infection showed an increase in their titers at about 1.2-fold of the initial infection (Figures $5 \mathrm{~B}$ and $\mathrm{C}$ ). The immune-stimulatory tendency of YC feeding on anti-PR8-specific IgA and IgG titers in serum and BALF was detected in reinfected mice but was insignificant, unlike the effects of $\mathrm{YC}$ in the initial infection. 


\section{DISCUSSION}

Oral probiotics not only influence the intestinal tract directly but also have immunomodulatory effects at distant sites (Meydani and Ha, 2000; KoppHoolihan, 2001), such as inflammatory bowel diseases (Lorea Baroja et al., 2007; Shadnoush et al., 2015), pulmonary infections (Alexandre et al., 2013; VientósPlotts et al., 2017), cancer (Lê et al., 1986), and atopic dermatitis (Matsumoto et al., 2007; Jain et al., 2010) in both animal models and human subjects. Recently, much focus has been placed on important contributions of the intestinal microbiome in lung immunity, including influenza virus pathogenesis (Esposito et al., 2014; Belkacem et al., 2017; Pu et al., 2017; McAleer and Kolls, 2018). Clinical studies have also shown that probiotics decrease bacterial and viral respiratory tract infections (Forsythe, 2014; Jespersen et al., 2015). To study the immunomodulatory effects of gut microbiota in IAV pathogenesis, we analyzed the effects of $L$. bulgaricus OLL1073R-1 YC on the local and systemic immunity of IAV-infected mice treated with the widely used antiviral neuraminidase inhibitor OSV, because OSV has suppressive effects on the development of the adaptive immune responses after IAV infection in mice and humans (Takahashi et al., 2010; Shinahara et al., 2013; Marois et al., 2015).

Influenza A virus has caused epidemics annually and pandemics several times each century with considerable morbidity and mortality worldwide. The World Health Organization estimates that 3 to 5 million severe influenza virus-related respiratory infections and up to 500,000 deaths occur worldwide every year (Stöhr, 2003). The antiviral neuraminidase inhibitors OSV, zanamivir, and peramivir are currently used for the treatment of influenza-related complications (Hayden et al., 1999; Aoki et al., 2003; Marois et al., 2015).
These inhibitors impair the release of new influenza virions from infected cells by blocking the actions of viral neuraminidases, resulting in effective suppression of viral RNA replication and viral antigen production. Despite the positive effects of these antiviral agents on influenza infection, we reported previously that OSV significantly suppresses the production of antiviral SIgA in the airway and mildly suppresses serum antiviral IgG levels in mice and pediatric patients, resulting in increases in re-infection rates in children in the subsequent year, probably because of the reduced viral antigen levels in the respiratory mucosa (Takahashi et al., 2010, 2012; Shinahara et al., 2013) and to the suppressed effector and central memory $\mathrm{CD} 8^{+}$T-cell responses to influenza virus (Marois et al., 2015).

To overcome this problem, in the current study we analyzed the immune stimulatory effects of $L$. bulgaricus OLL1073R-1 YC feeding on the levels of murine antiviral mucosal S-IgA and IgG in BALF and IgG and IgA in serum, which were suppressed by OSV treatment. We also analyzed the stimulatory effects of $L$. bulgaricus OLL1073R-1 YC feeding on the protective immunities of BALF and serum antibodies. In our experiments, we used a limited dose of IAV PR8 (0.5 pfu, $20 \%$ of $\mathrm{LD}_{50}$ ) for the initial infection to produce a mild infection model in mice that may mimic most infection cases in humans. The mild nature of the infection was reflected by the lack of deaths in infected animals used in these experiments and rapid recovery of loss of BW associated with the infection. Under the conditions used herein, feeding of $\mathrm{YC}$ once daily during the experimental period in the $(\mathrm{MC}+\mathrm{YC})$ infection group did not have immune stimulatory effects on antiviral $\operatorname{IgA}$ and $\operatorname{IgG}$ levels in serum and antiviral S-IgA and IgG levels in BALF compared with the $(\mathrm{MC}+\mathrm{DW})$ infection group, but showed significant protection against $\mathrm{BW}$ loss compared with the $(\mathrm{MC}+\mathrm{DW})$ group.

Table 1. Suppressive effects of oseltamivir (OSV) on induction of influenza A virus (PR8)-specific IgG subtypes in serum and bronchoalveolar lavage fluid (BALF) and immune-stimulating effects of yogurt culture (YC) feeding ${ }^{1}$

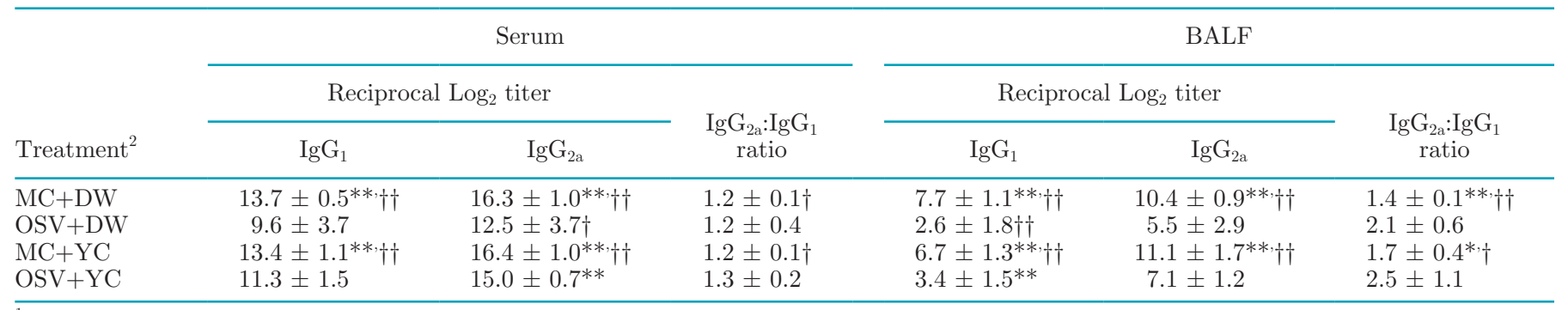

${ }^{1}$ Serum and BALF samples were prepared at $14 \mathrm{~d}$ post-infection and anti-PR8-specific IgG subtype levels and their ratios were determined by ELISA. Data are mean \pm SD.

${ }^{2}$ Mice received orally yogurt culture (YC) or distilled water (DW), as a control, once daily for 35 d. During the course at d 22 , the mice were infected with PR8. Immediately after infection, the mice also received orally $50 \mu \mathrm{g}$ of oseltamivir (OSV) or $5 \%$ methylcellulose (MC) as a vehicle, or $\mathrm{MC}$ alone twice daily ( $\mathrm{n}=10$ per group) at an interval of $12 \mathrm{~h}$ for $13 \mathrm{~d}$.

${ }^{*} P<0.05,{ }^{* *} P<0.01$, versus OSV $+\mathrm{DW} ; \dagger P<0.05, \dagger \dagger P<0.01$ versus OSV $+\mathrm{YC}$, by ANOVA and Bonferroni post-test. 
In contrast, the $(\mathrm{OSV}+\mathrm{YC})$ infection group showed mild but significant recovery of the suppressed levels of antiviral $\operatorname{Ig} \mathrm{A}$ in serum, S-IgA in BALF, and antiviral IgG in serum, as well as significant recovery of neutralization activities of antibodies in BALF and serum IgG compared with the (OSV+DW) infection group.
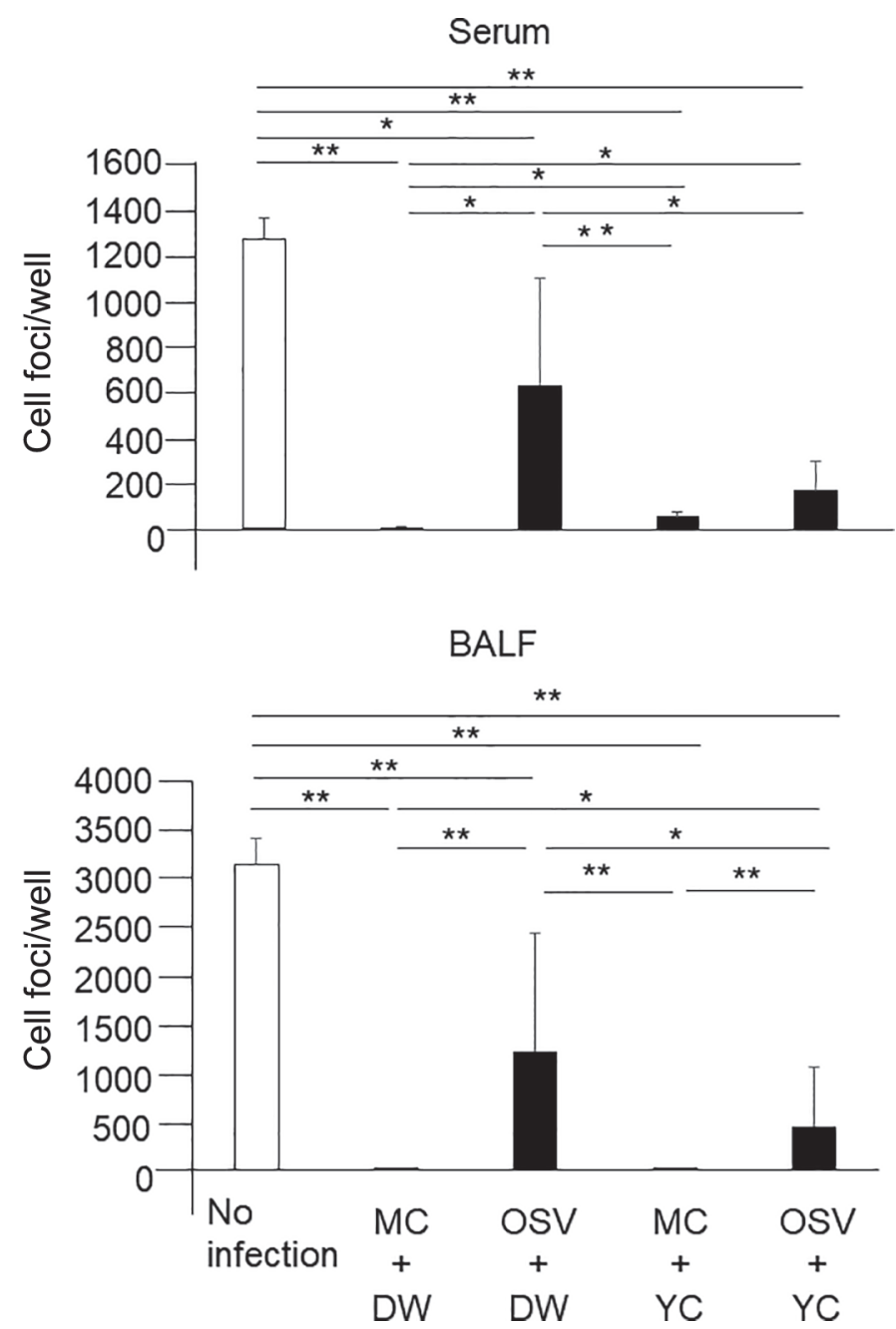

Figure 4. Oseltamivir (OSV) suppressed and yogurt culture (YC) stimulated neutralizing activity against influenza A virus/Puerto Rico/8/34 (H1N1) (PR8) in serum and bronchoalveolar lavage fluid (BALF) in Madin-Darby canine kidney (MDCK) cells. Mice ingested $\mathrm{YC}$ or distilled water (DW) for $35 \mathrm{~d}$. During treatment, mice were infected with PR8 at d 22 followed by treatment with OSV or methylcellulose (MC) twice daily until the end of schedule, as shown in Figure 1A. At $14 \mathrm{~d}$ post-infection, serum and BALF were prepared and then neutralizing activities were measured. Purified IgG $(2 \mu \mathrm{g})$ from serum of each group with PR8 (1,450 pfu) (A) and $50 \mu \mathrm{L}$ of BALF with PR8 (3,000 pfu) (B) were preincubated at $37^{\circ} \mathrm{C}$ for $1 \mathrm{~h}$. Each mixture was then incubated with a confluent monolayer of MDCK cells at $37^{\circ} \mathrm{C}$ for $1 \mathrm{~h}$ for infection. After $16 \mathrm{~h}$, the cells were fixed with $4 \%$ paraformaldehyde in PBS, permeabilized with $0.3 \%$ Triton $\mathrm{X}-100$ in PBS, and then visualized with anti-influenza virus nucleoprotein monoclonal antibody. Data are mean \pm SD numbers of infected cel foci per well ( $\mathrm{n}=10$ per group); ${ }^{*} P<0.05,{ }^{* *} P<0.01$, by ANOVA and Bonferroni post-test.
Furthermore, YC feeding significantly stimulated Th2type immunity of $\mathrm{IgG}_{1}$ levels in BALF and Th1-type immunity of $\operatorname{IgG}_{2 \mathrm{a}}$ levels in serum, which were both suppressed by OSV treatment, without changing $\operatorname{IgG}_{2 \mathrm{a}}$ : $\mathrm{IgG}_{1}$ (Th1:Th2) ratio.

The immune-stimulatory effects of $\mathrm{YC}$ feeding on humoral immune responses were confirmed in re-infected mice. Although mice were re-infected with an extremely high dose of PR8 (10,000 pfu), none of the animals died and relative PA expression levels in all groups were less than $1 / 100$ of the initial infection, indicating that protective immunity induced by initial infection was effective and sustained. Under the experimental conditions, an immune-stimulatory tendency of YC feeding on humoral immune responses was detected but insignificant, unlike the effects of $\mathrm{YC}$ in the initial infection.

It has been reported that L. bulgaricus OLL1073R-1 $\mathrm{YC}$ and its immune-stimulatory product of EPS enhance natural killer cell activation through induction of IFN- $\gamma$ in the spleen of mice, and the effect is abrogated in IFN- $\gamma$ knockout mice and in MyD88 (myeloid differentiation factor 88) knockout mice (Makino et al., 2016). Furthermore, IFN- $\gamma$ production from spleen cells stimulated by EPS is completely blocked by treatment with both anti-IL-12 and anti-IL-18 antibodies in vitro (Makino et al., 2016). In addition, it has been reported that the cytokines IL-21 and IFN- $\gamma$, which are secreted from Th1 cells, are essential for the induction of protective neutralizing $\operatorname{IgG}_{2}$ antibodies (Miyauchi et al., 2016). These findings partly explain the immune-stimulating mechanisms of $L$. bulgaricus OLL1073R-1 YC feeding on Th1-type immunity and neutralizing activity of antiviral $\operatorname{IgG}_{2 \mathrm{a}}$ level in serum but does not explain the stimulation of Th2-type immunity of antiviral $\operatorname{IgG}_{1}$ levels in BALF. To elucidate the mechanisms of immune stimulatory effects of L. bulgaricus OLL1073R-1 YC and EPS on Th1-, Th2-, and Th17-type intestinal mucosal immunity, as well as effector and central memory $\mathrm{CD} 8^{+} \mathrm{T}$-cell responses, further studies are required along with screening of target molecules of their actions. These studies are underway in our laboratories.

\section{CONCLUSIONS}

Our data show that L. bulgaricus OLL1073R-1 YC feeding at the time of OSV treatment in IAV infection stimulates the induction of acquired humoral immunity of anti-PR8-specific S-IgA and IgG in BALF and anti-PR8-specific IgG and IgA in serum, which were suppressed by OSV treatment in mice. In addition, YC feeding also mildly enhanced protective immunity, which was suppressed by OSV treatment, as monitored by IAV neutralizing activities of IgG in serum and antibodies in BALF. The immune-stimulatory tendency of 
YC feeding on humoral immune responses was also detected in re-infected mice, albeit insignificantly, unlike the effects in the initial infection. We conclude that $L$. bulgaricus OLL1073R-1 YC feeding may be effective in stimulating humoral immunity against IAV infection, particularly in patients treated with antiviral neuraminidase inhibitors, and may play a supporting role in achieving a more effective treatment of influenza.
A
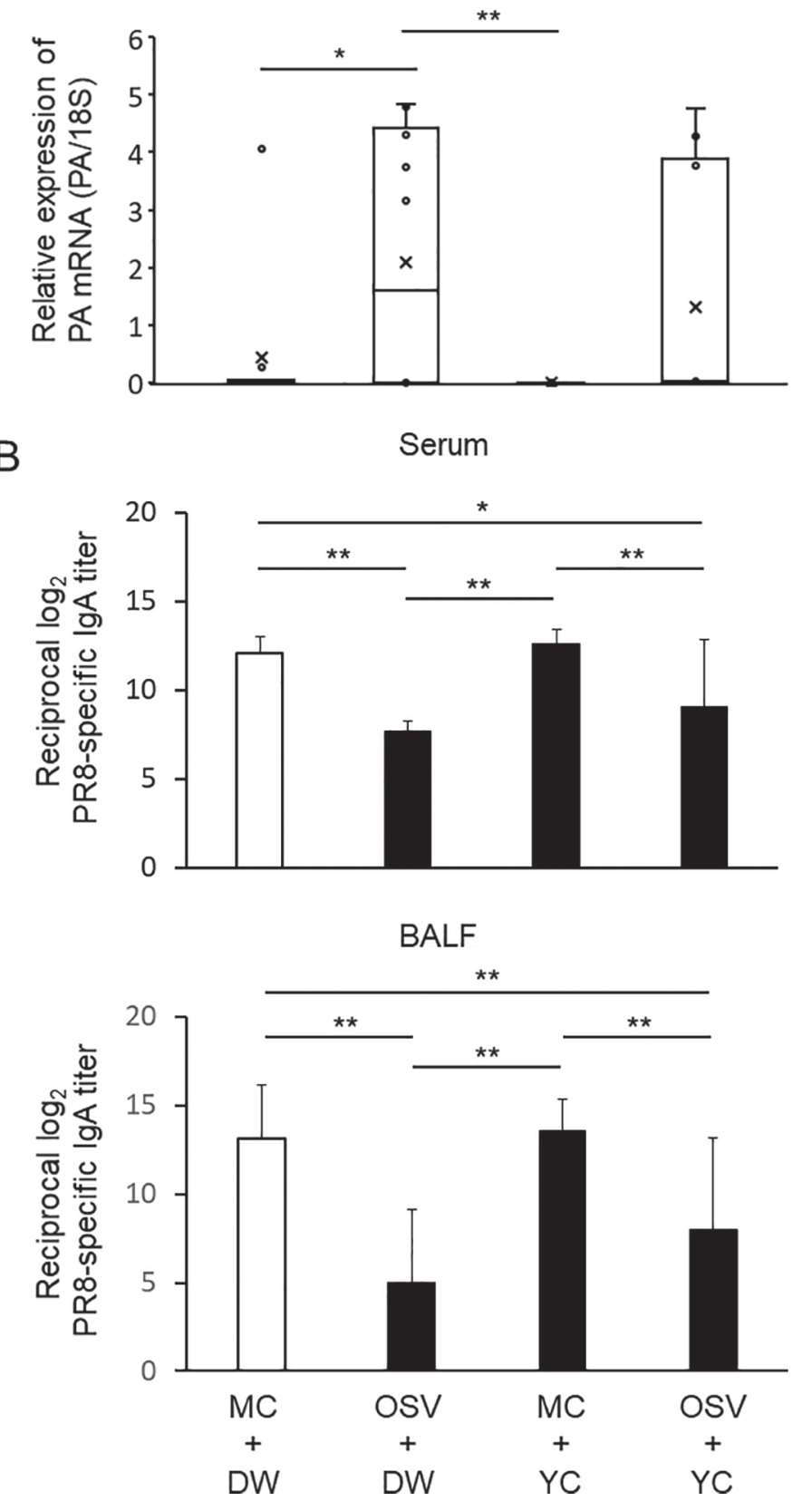

C

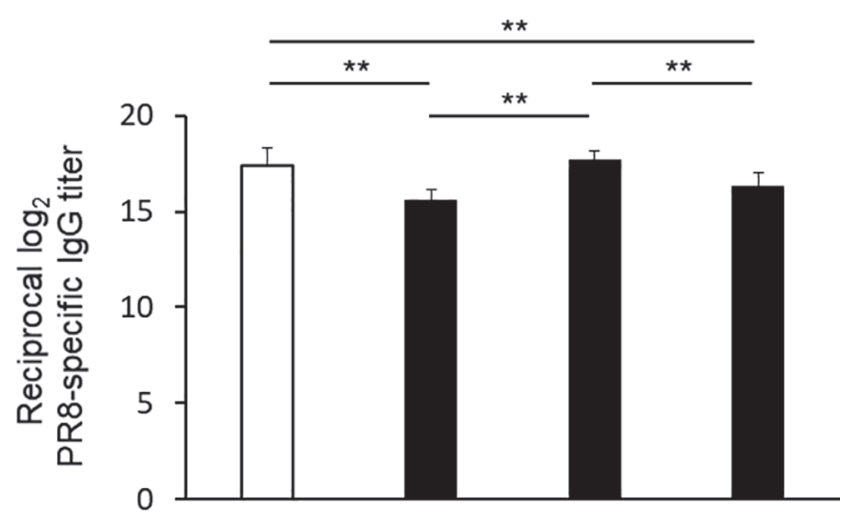

\section{BALF}

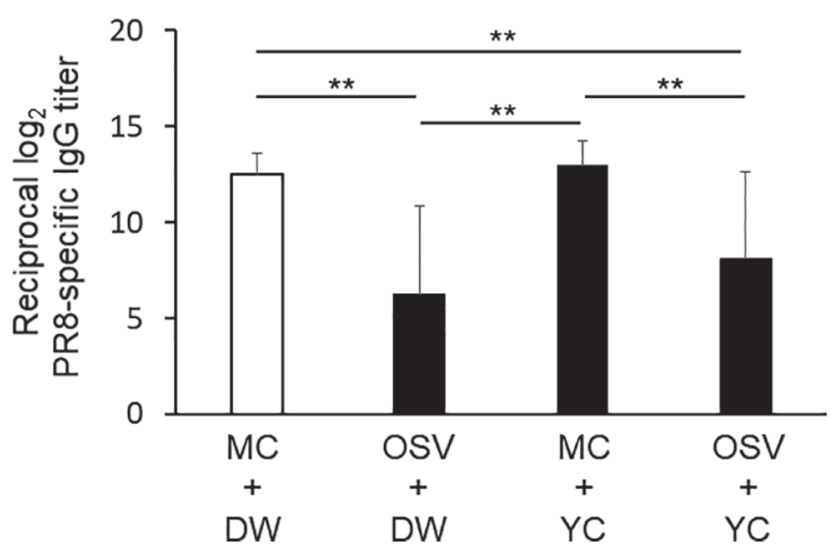

Figure 5. Effects of Lactobacillus bulgaricus OLL1073R-1 yogurt culture (YC) feeding on protective immunity in re-infected mice. After initial infection for $25 \mathrm{~d}, 4$ groups of mice were re-infected with influenza A virus/Puerto Rico/8/34 (H1N1) (PR8) at a dose of 10,000 pfu. (A) Viral RNA polymerase $\alpha$ (PA) expression levels normalized to $18 \mathrm{~S}$ in the lungs at $4 \mathrm{~d}$ after re-infection were analyzed and expressed as median values of 10 mice per group. Anti-PR8-specific IgA titers (B) and IgG titers (C) in serum and bronchoalveolar lavage fluid (BALF) were also measured by ELISA. Data are shown as bar charts for the groups of $(\mathrm{MC}+\mathrm{DW}),(\mathrm{OSV}+\mathrm{DW}),(\mathrm{MC}+\mathrm{YC})$, and $(\mathrm{OSV}+\mathrm{YC})$, as indicated on the $\mathrm{x}$-axis, and expressed as mean $\pm \mathrm{SD}\left(\mathrm{n}=10\right.$ per group). $P$-values were determined by ANOVA and Bonferroni post-test: ${ }^{*} P<0.05$ and ${ }^{* *} P<0.01 . \mathrm{MC}=$ methylcellulose; $\mathrm{DW}=$ distilled water; $\mathrm{OSV}=$ oseltamivir. 


\section{ACKNOWLEDGMENTS}

This study was supported in part by a Grant-inAid for Scientific Research (B) (\#16H05348) from the Ministry of Education, Culture, Sports, Science and Technology of Japan (Tokyo), a grant from the Medical Research and Development Programs Focused on Technology Transfer of Japan Agency (Tokyo), AMED (\#18im0210112), as well as a grant from Meiji Co. Ltd. (Kanagawa, Japan). The funders had no role in study design, data collection and analysis, decision to publish, or preparation of the manuscript.

\section{REFERENCES}

Alexandre, Y., G. Le Blay, S. Boisramé-Gastrin, F. Le Gall, G. HéryArnaud, S. Gouriou, S. Vallet, and R. Le Berre. 2013. Probiotics: A new way to fight bacterial pulmonary infections? Med. Mal. Infect. 44:9-17. https://doi.org/10.1016/j.medmal.2013.05.001.

Aoki, F. Y., M. D. Macleod, P. Paggiaro, O. Carewicz, A. E. I. Sawy, C. Wat, M. Griffiths, E. Waalberg, and P. Ward.IMPACT Study Group. 2003. Early administration of oral oseltamivir increases the benefits of influenza treatment. J. Antimicrob. Chemother. 51:123-129. https://doi.org/10.1093/jac/dkg007.

Belkacem, N., N. Serafini, R. Wheeler, M. Derrien, L. Boucinha, A. Couesnon, N. Cerf-Bensussan, I. G. Boneca, J. P. Di Santo, M. K. Taha, and R. Bourdet-Sicard. 2017. Lactobacillus paracasei feeding improves immune control of influenza infection in mice. PLoS One 12:e0184976. https://doi.org/10.1371/journal.pone.0184976.

de Vos, P., Z. Mujagic, B. J. de Haan, R. J. Siezen, P. A. Bron, M. Meijerink, J. M. Wells, A. A. M. Masclee, M. V. Boekschoten, M. M. Faas, and F. J. Troost. 2017. Lactobacillus plantarum strains can enhance human mucosal and systemic immunity and prevent non-steroidal anti-inflammatory drug induced reduction in T regulatory cells. Front. Immunol. 8:1000. https://doi.org/10.3389/ fimmu.2017.01000.

Esposito, S., D. Rigante, and N. Principi. 2014. Do children's upper respiratory tract infections benefit from probiotics? BMC Infect. Dis. 14:194. https://doi.org/10.1186/1471-2334-14-194.

Forsythe, P. 2014. Probiotics and lung immune responses. Ann. Am. Thorac. Soc. 11(Suppl. 1):S33-37. https://doi.org/10.1513/ AnnalsATS.201306-156MG.

Gillim-Ross, L., and K. Subbarao. 2006. Emerging respiratory viruses: Challenges and vaccine strategies. Clin. Microbiol. Rev. 19:614636. https://doi.org/10.1128/CMR.00005-06.

Hayden, F. G., R. L. Atmar, M. Schilling, C. Johnson, D. Poretz, D. Paar, L. Huson, P. Ward, and R. G. Mills. 1999. Use of the selective oral neuraminidase inhibitor oseltamivir to prevent influenza. N. Engl. J. Med. 341:1336-1343. https://doi.org/10.1056/ NEJM199910283411802.

Jain, S., H. Yadav, P. R. Sinha, S. Kapila, Y. Naito, F. Marotta, and J. Turk. 2010. Anti-allergic effects of probiotic Dahi through modulation of the gut immune system. Turk. J. Gastroenterol. 21:244-250. https://doi.org/10.4318/tjg.2010.0095.

Jespersen, L., I. Tarnow, D. Eskesen, C. M. Morberg, B. Michelsen, S. Bugel, L. O. Dragsted, G. T. Rijkers, and P. C. Calder. 2015. Effect of Lactobacillus paracasei ssp. paracasei, L. casei 431 on immune response to influenza vaccination and upper respiratory tract infections in healthy adult volunteers: a randomized, doubleblind, placebo-controlled, parallel-group study. Am. J. Clin. Nutr. 101:1188-1196. https://doi.org/10.3945/ajcn.114.103531.

Kopp-Hoolihan, L. 2001. Prophylactic and therapeutic uses of probiotics: A review. J. Am. Diet. Assoc. 101:229-238.

Lê, M. G., L. H. Moulton, C. Hill, and A. Kramer. 1986. Consumption of dairy products and alcohol in a case-control study of breast cancer. J. Natl. Cancer Inst. 77:633-636.
Lorea Baroja, M., P. V. Kirjavainen, S. Hekmat, and G. Reid. 2007. Anti-inflammatory effects of probiotic yogurt in inflammatory bowel disease patients. Clin. Exp. Immunol. 149:470-479. https:// doi.org/10.1111/j.1365-2249.2007.03434.x.

Makino, S., S. Ikegami, H. Kano, T. Sashihara, H. Sugano, H. Horiuchi, T. Saito, and M. Oda. 2006. Immunomodulatory effects of polysaccharides produced by Lactobacillus delbrueckii ssp. bulgaricus OLL1073R-1. J. Dairy Sci. 89:2873-2881. https://doi.org/10 .3168/jds.S0022-0302(06)72560-7.

Makino, S., S. Ikegami, A. Kume, H. Horiuchi, H. Sasaki, and N. Orii. 2010. Reducing the risk of infection in the elderly by dietary intake of yoghurt fermented with Lactobacillus delbrueckii ssp. bulgaricus OLL1073R-1. Br. J. Nutr. 104:998-1006. https://doi.org/10.1017/ S000711451000173X.

Makino, S., A. Sato, A. Goto, M. Nakamura, M. Ogawa, Y. Chiba, J. Hemmi, H. Kano, K. Takeda, K. Okumura, and Y. Asami. 2016. Enhanced natural killer cell activation by exopolysaccharides derived from yogurt fermented with Lactobacillus delbrueckii ssp. bulgaricus OLL1073R-1. J. Dairy Sci. 99:915-923. https://doi.org/10 .3168/jds.2015-10376.

Marois, I., A. Cloutier, É. Garneau, O. Lesur, and M. V. Richter. 2015. The administration of oseltamivir results in reduced effector and memory CD8+ T cell responses to influenza and affects protective immunity. FASEB J. 29:973-987. https://doi.org/10.1096/fj .14-260687.

Matsumoto, M., A. Aranami, A. Ishige, K. Watanabe, and Y. Benno. 2007. LKM512 yogurt consumption improves the intestinal environment and induces the T-helper type 1 cytokine in adult patients with intractable atopic dermatitis. Clin. Exp. Allergy 37:358-370. https://doi.org/10.1111/j.1365-2222.2007.02642.x.

McAleer, J. P., and J. K. Kolls. 2018. Contribution of the intestinal microbiome in lung immunity. Eur. J. Immunol. 48:39-49. https:/ /doi.org/10.1002/eji.201646721.

Meydani, S. N., and W. K. Ha. 2000. Immunologic effects of yogurt. Am. J. Clin. Nutr. 71:861-872. https://doi.org/10.1093/ajcn/71 .4 .861 .

Miyauchi, K., A. Sugimoto-Ishige, Y. Harada, Y. Adachi, Y. Usami, T. Kaji, K. Inoue, H. Hasegawa, T. Watanabe, A. Hijikata, S. Fukuyama, T. Maemura, M. Okada-Hatakeyama, O. Ohara, Y Kawaoka, Y. Takahashi, T. Takemori, and M. Kubo. 2016. Protective neutralizing influenza antibody response in the absence of T follicular helper cells. Nat. Immunol. 17:1447-1458. https://doi .org/10.1038/ni.3563.

Moscona, A. 2005. Neuraminidase inhibitors for influenza. N. Engl. J. Med. 353:1363-1373. https://doi.org/10.1056/NEJMra050740.

Nagai, T., S. Makino, S. Ikegami, H. Itoh, and H. Yamada. 2011. Effects of oral administration of yogurt fermented with Lactobacillus delbrueckii ssp. bulgaricus OLL1073R-1 and its exopolysaccharides against influenza virus infection in mice. Int. Immunopharmacol. 11:2246-2250. https://doi.org/10.1016/j.intimp.2011.09.012.

NRC. (National Research Council, Institute for Laboratory Animal Research). 1996. Guide for the Care and Use of Laboratory Animals. https://grants.nih.gov/grants/olaw/guide-for-the-care-and -use-of-laboratory-animals.pdf.

Peiris, J. S., K. P. Hui, and H. L. Yen. 2010. Host response to influenza virus: Protection versus immunopathology. Curr. Opin. Immunol. 22:475-481. https://doi.org/10.1016/j.coi.2010.06.003.

Perdigón, G., R. Fuller, and R. Raya. 2001. Lactic acid bacteria and their effect on the immune system. Curr. Issues Intest. Microbiol. $2: 27-42$.

Pu, F., Y. Guo, M. Li, H. Zhu, S. Wang, X. Shen, M. He, C. Huang, and F. He. 2017. Yogurt supplemented with probiotics can protect the healthy elderly from respiratory infection: A randomized controlled open-label trial. Clin. Interv. Aging 12:1223-1231. https:// doi.org/10.2147/CIA.S141518.

Rouse, B. T., and S. Sehrawat. 2010. Immunity and immunopathology to viruses: What decides the outcome? Nat. Rev. Immunol. 10:514-526. https://doi.org/10.1038/nri2802.

Sawabuchi, T., S. Suzuki, K. Iwase, C. Ito, D. Mizuno, H. Togari, I. Watanabe, S. R. Talukder, J. Chida, and H. Kido. 2009. Boost of mucosal secretory immunoglobulin A response by clarithromy- 
cin in paediatric influenza. Respirology 14:1173-1179. https://doi org/10.1111/j.1440-1843.2009.01639.x.

Shadnoush, M., R. S. Hosseini, A. Khalilnezhad, L. Navai, H. Goudarzi, M. Vaezjalali. Korean, and J. Gastroenterol. 2015. Effects of probiotics on gut microbiota in patients with inflammatory bowel disease: A double-blind, placebo-controlled clinical trial. Korean J. Gastroenterol. 65:215-221. https://doi.org/10.4166/kjg.2015.65 .4 .215 .

Shinahara, W., E. Takahashi, T. Sawabuchi, M. Arai, N. Hirotsu, Y. Takasaki, S. Shindo, K. Shibao, T. Yokoyama, K. Nishikawa, M. Mino, M. Iwaya, Y. Yamashita, S. Suzuki, D. Mizuno, and H. Kido. 2013. Immunomodulator clarithromycin enhances mucosal and systemic immune responses and reduces re-infection rate in pediatric patients with influenza treated with antiviral neuraminidase inhibitors: A retrospective analysis. PLoS One 8:e70060. https://doi.org/10.1371/journal.pone.0070060.

Stöhr, K. 2003. Preventing and treating influenza. BMJ 326:12231224. https://doi.org/10.1136/bmj.326.7401.1223.

Takahashi, E., K. Kataoka, K. Fujii, J. Chida, D. Mizuno, M. Fukui, I. Hiro-O, K. Fujihashi, and H. Kido. 2010. Attenuation of inducible respiratory immune responses by oseltamivir treatment in mice infected with influenza A virus. Microbes Infect. 12:778-783. https:/ /doi.org/10.1016/j.micinf.2010.04.013.

Takahashi, E., K. Kataoka, I. L. Irene, K. Konoha, K. Fujii, J. Chida, D. Mizuno, K. Fujihashi, and H. Kido. 2012. Oral clarithromycin enhances airway immunoglobulin A ( $\operatorname{Ig}$ A) immunity through induction of IgA class switching recombination and B-cell-activating factor of the tumor necrosis factor family molecule on mucosal dendritic cells in mice infected with influenza A virus. J. Virol. 86:10924-10934. https://doi.org/10.1128/JVI.01207-12.

Vientós-Plotts, A. I., C. A. Ericsson, R. Hansjorg, and C. R. Reinero. 2017. Oral probiotics alter healthy feline respiratory microbiota. Front. Microbiol. 8:1287. https://doi.org/10.3389/fmicb.2017 .01287 .

Yamamoto, Y., K. Fujino, J. Saruta, T. Takahashi, M. To, S. Fuchida, T. Shimizu, Y. Kamata, K. Misawa, and K. Tsukinoki. 2017. Effects of yogurt fermented with Lactobacillus delbrueckii ssp. bulgaricus OLL1073R-1 on the IgA flow rate of saliva in elderly persons residing in a nursing home: A before-after non-randomised intervention study. Gerodontology 34:479-485. https://doi.org/10 $.1111 /$ ger.12296.

Yamane, K., I. L. Indalao, J. Chida, Y. Yamamoto, M. Hanawa, and H. Kido. 2014. Diisopropylamine dichloroacetate, a novel pyruvate dehydrogenase kinase 4 inhibitor, as a potential therapeutic agent for metabolic disorders and multiorgan failure in severe influenza. PLoS One 9:e98032. https://doi.org/10.1371/journal.pone .0098032 . 